INTERNATIONAL JOURNAL OF MULTIDISCIPLINARY RESEARCH AND ANALySis

ISSN(print): 2643-9840, ISSN(online): 2643-9875

Volume 04 Issue 12 December 2021

DOI: 10.47191/ijmra/v4-i12-18, Impact Factor: 6.072

Page No.- $1895-1900$

\title{
Development of Plant Physiology E-Modules Based on Contextual Teaching and Learning (CTL) on Photosynthesis and Metabolism Materials Nitrogen Using Software Appypie of Results Student Learning Biology
}

\author{
Sestry Ayu Ruganda ${ }^{1}$, Violita ${ }^{2}$, Moralita Chatri ${ }^{3}$, Fitri Arsih ${ }^{4}$ \\ ${ }^{1}$ Master Degree Program of Biology Education, Faculty of Mathematics and Sciences, Padang State University, Jl. Prof. Dr. West \\ Padang Freshwater Hamka - 25131 Indonesia \\ 2,3,4 Lecturer of Biology Department, Faculty of Mathematics and Sciences, Padang State University, Jl. Prof. Dr. West Freshwater \\ Hamka Padang-25131, Indonesia
}

ABSTRACT: The strategy and implementation of learning is strongly influenced by the development of science and technology. So the technology that is currently developing must be integrated into the learning process to improve the quality of learning. One of the technology integration is E-Modul. E-Modul is a form of presentation of self-study materials that are arranged systematically into the smallest learning units to achieve certain learning objectives which are presented in an electronic format for each learning activity. E-Modules developed using a contextual approach will This causes students to get more meaningful learning, because they can relate the material to real everyday life. E-Modules are presented systematically so that they contain relevant text, images and videos. Therefore, Appypie Software is used in the development of the Plant Physiology E-Module. The purpose of this research is to produce an E-Module of Plant Physiology based on CTL on the material of Photosynthesis and Nitrogen Metabolism using Appypie Software which is valid, practical and effective. This type of research is development research using the Plomp model. The development phase of this model begins with the Preliminary Research Phase, Development or Prototyping Phase, and the Assessment Phase. The instruments in this study were in the form of a validity assessment sheet, a practicality assessment sheet, a skill and attitude competency assessment sheet and multiple choice questions to assess knowledge competence. The data analysis technique is validity, practicality using modified Likert scale scoring and effectiveness data using t-test using SPSS version 17. The results showed that the CTL-based Plant Physiology EModule on the materials of Photosynthesis and Nitrogen Metabolism was very valid with a value of $92.21 \%$. The practicality assessment by the lecturers scored $95 \%$ with very practical criteria and the student assessment with a score of $82.17 \%$ with very practical criteria. The results of the effectiveness test showed that the class that used the CTL-based Plant Physiology E-Module had a higher score than the class that did not use the CTL-based Plant Physiology E-Module, so the use of the E-Module equipped with pictures, animations and videos could help students understand material. It can be concluded that the CTL-based Plant Physiology E-Module that has been developed is in the very valid, very practical, and very effective category in improving student learning outcomes.

KEYWORDS: Contextual Teaching and Learning (CTL), E-Module Development, Appypie Software.

\section{INTRODUCTION}

Education is one of the main investments for the Indonesian people, because it is a means to form quality human resources, both physically and mentally. Structuring quality education, can be pursued through a quality learning system in schools or in other educational institutions.

In the current millennial era, where the internet and Information and Communication Technology (ICT) are the main things and are very influential in everyday life for all people, including in education (Astutia, 2017). The strategy and implementation of learning is strongly influenced by the development of science and technology. So the technology that is currently developing must be integrated into the learning process to improve the quality of learning. One of the technology integration is in learning 


\section{Development of Plant Physiology E-Modules Based on Contextual Teaching and Learning (CTL) on Photosynthesis and Metabolism Materials Nitrogen Using Software Appypie of Results Student Learning Biology}

media. Learning media is everything both physical and technical in the learning process that can help educators to deliver learning in order to achieve the learning objectives that have been formulated.

Based on the results of interviews with UNP Biology students in 2018 that some students quite experienced difficulties in understanding the material in the Plant Physiology course (40\%). This is caused by several obstacles, namely the presentation of material during the Covid 19 pandemic that took place less effectively and at the current condition lectures are conducted online and the internet network is not good. So that at this time it is hoped that teaching materials in the form of E-Modules are equipped with text, images, videos, evaluations, and relevant references so that students can use them independently.

Based on the results of the problems and student needs for learning media for Biology UNP students, 96\% of students stated that it was necessary to develop E-Modules in Plant Physiology learning. Students are more interested and enjoy learning that is carried out using interactive and easy-to-understand teaching materials and includes text, images, videos, evaluations and references.

In addition to using E-Modules, the learning model will determine the success of the learning process. One approach that can be combined with E-Modules is Contextual Teaching and Learning (CTL). Contextual and Teaching Learning (CTL) is a process of approach that is very different from other approaches, it is said to be very different because this approach not only teaches students to know the lesson, but can also help students to know the lesson by relating it to everyday life. student.

The use of Contextual Teaching and Learning (CTL) -based E-Modules will be easier for students to use if they are assisted with Appypie Software. This is in accordance with Astuti (2018) who revealed that Appypie is a website that provides templates for making android applications for free and paid. In making with Appypie must be connected directly to the internet that is online. The learning materials that are filled in can contain text, images, videos, links, and interactive quizzes so that this electronic module can be accessed with the help of a computer that has been integrated with software that supports accessing E-Modules via Android.

E-Module based on Contextual Teaching and Learning (CTL) approach using Appypie Software can be applied to Plant Physiology courses. One of the materials in plant physiology used is Photosynthesis and Nitrogen Metabolism. This material is important for students to learn and understand because it is informative and directly related to the environment and important concepts that can be studied independently by students to develop their knowledge.

Based on the problems raised, the author will conduct a research "Development of an E-Module of Plant Physiology Based on Contextual Teaching and Learning (CTL) on Photosynthesis and Nitrogen Metabolism Materials by Using Appypie Software on Biology Student Learning Outcomes".

\section{METHOD}

This type of research is development research using the Plomp model. The development phase of this model begins with 1) Preliminary research phase, at this stage a problem analysis, needs analysis, RPS analysis, and analysis of teaching materials used 2) Development or prototyping phase, at this stage the E-Module design is carried out then validation and practicalization and 3) Assessment phase, in the last stage an effectiveness test is carried out which aims to determine student learning outcomes. The subjects of this research are Biology Education students of UNP Academic Year 2019.

The research object is the CTL-based Plant Physiology E-Module on Photosynthesis and Nitrogen Metabolism Materials. The instruments in this study were in the form of a validity assessment sheet, a practicality assessment sheet, a skill and attitude competency assessment sheet and multiple choice questions to assess knowledge competence. Data analysis technique validity, practicality using modified Likert scale scoring and effectiveness data Normality test using Kolmogorov-Smirnov, homogeneity test using Levene test, while hypothesis testing using T-test using SPSS version 17.

\section{RESULTS AND DISCUSSION}

\section{A. Research Result}

\section{Validity Results}

Based on the results of the average validity that has been carried out by the expert team, the average result is 92.21 with a very valid category. The percentage of each assessment aspect includes aspects: didactic, constructive, and technical. For more details, it can be seen in Figure 1 as follows: 
Development of Plant Physiology E-Modules Based on Contextual Teaching and Learning (CTL) on Photosynthesis and Metabolism Materials Nitrogen Using Software Appypie of Results Student Learning Biology

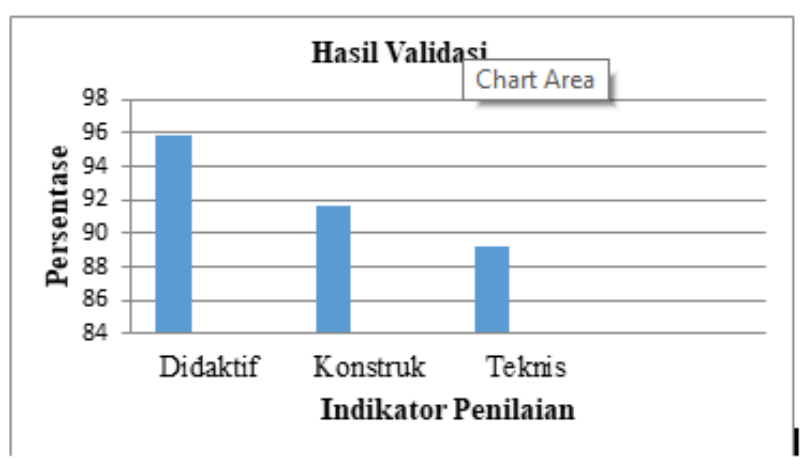

Figure 1. Expert Team Validation Results

\section{Practical Results}

Based on the results of practical tests that have been carried out in small groups, large groups and lecturers in the Plant Physiology course, it can be seen in Figure 2 as follows:

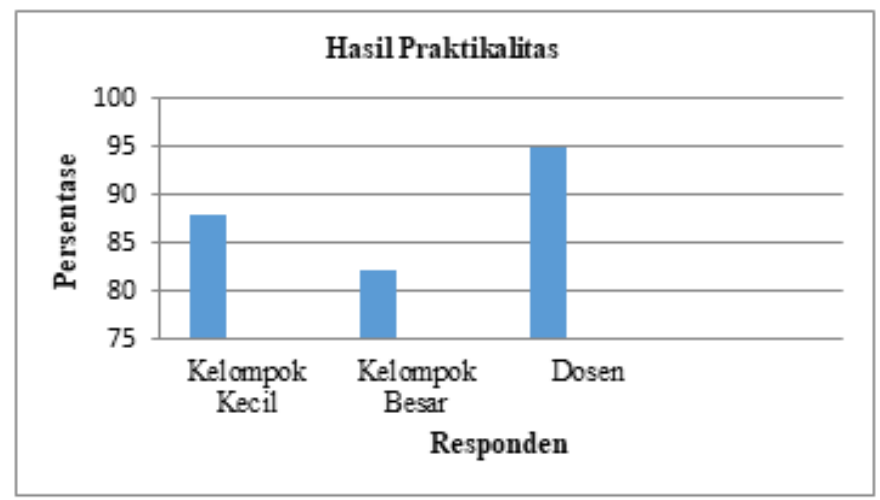

Figure 2. Practical Results for Several Respondents

\section{Effectiveness Results}

Based on the results of the effectiveness test that has been carried out the assessment of student learning outcomes includes knowledge competence, attitude competence, and skill competence. Knowledge competency assessment is taken using an instrument in the form of a test (objective question). The results of the assessment were obtained from the posttest $t$ after the learning was carried out, while the results can be seen in Table 1 as follows:

Table 1. Knowledge Competency Assessment Results

\begin{tabular}{|l|l|l|l|l|l|}
\hline Class & $\mathbf{N}$ & $\mathbf{X m i n}$ & $\mathbf{X m a x}$ & $\overline{\boldsymbol{X}}$ & Standard Deviation \\
\hline Experiment & 28 & 48.00 & 84.00 & 68.50 & 8.77 \\
\hline Control & 27 & 32.00 & 76.00 & 60.44 & 10.88 \\
\hline
\end{tabular}

Furthermore, the analysis of the knowledge competency data was obtained using the SPSS version 17 application. The normality test used the Kolmogorov-Smirnov test, the homogeneity test used the Levene test, while the hypothesis test used the $T$ test . To be more clearly presented in Table 2 as follows:

Table 2. Normality, Homogeneity and Hypothesis Test Results

\begin{tabular}{|c|l|l|l|l|}
\hline Parameter & Class & Signification & Provision Absolute & Information \\
\hline \multirow{2}{*}{ Normality } & Experiment & 0.080 & Significance $>0.05$ & $\begin{array}{l}\text { Significance } 0.080>0.05 \\
\text { (Normal) }\end{array}$ \\
\cline { 2 - 3 } Homogeneity & Control & 0.062 & Significance $>0.05$ & $\begin{array}{l}\text { Significance } 0.174>0.05 \\
\text { (Homogeneous) }\end{array}$ \\
\hline \multirow{2}{*}{ Hypothesis } & Experiment & 0.004 & Significance $<0.05$ & $\begin{array}{l}\text { Significance } 0.004 \\
<0.05 \\
\text { (H o rejected) }\end{array}$ \\
\cline { 2 - 3 } & Control & 0.004 & & \\
\hline
\end{tabular}




\section{Development of Plant Physiology E-Modules Based on Contextual Teaching and Learning (CTL) on Photosynthesis and Metabolism Materials Nitrogen Using Software Appypie of Results Student Learning Biology}

Based on Table 2 above, the normality test obtained that the significance is $0.080>0.05$ which indicates that the data is normally distributed. The homogeneity test obtained a significance of $0.174>0.05$ which indicates that the data has a homogeneous variance. Hypothesis testing obtained a significance of $0.004<0.05$ which indicates that $\mathrm{H}_{0}$ is rejected and $\mathrm{H}_{1}$ is accepted. So it can be concluded that the use of the CTL-based Plant Physiology E-Module has an effect on student knowledge competency learning outcomes.

The results of the attitude competency assessment were seen by using an observation instrument using an observation sheet. The results of the attitude competency assessment can be seen in Table 3 as follows:

Table 3. Results of Attitude Competency Assessment

\begin{tabular}{|l|l|l|l|l|l|}
\hline Class & \multicolumn{1}{|c|}{$\mathbf{N}$} & Amount & Average & Signification & Conclusion \\
\cline { 1 - 4 } Experiment & 28 & 2303 & 82.25 & \multirow{2}{*}{0.000} & $\begin{array}{l}\text { Significance } 0.000<0.05 \\
\text { (H o rejected, } \mathbf{H}_{1} \text { accepted) }\end{array}$ \\
\hline Control & 27 & 1981 & 73.37 & 0.000 & \\
\hline
\end{tabular}

The results of the T-test showed a significance value of $0.000<0.05$ so that $\mathrm{HO}$ was rejected. It can be concluded that it is concluded that the use of the CTL-based Plant Physiology E-Module has an effect on student attitude competency learning outcomes.

Furthermore, the results of the skill competency assessment were seen by using an observation instrument using an observation sheet. The results of the skills competency assessment can be seen in Table 4 as follows:

Table 4. Skills Competency Assessment Results

\begin{tabular}{|l|l|l|l|l|l|}
\hline Class & N & Amount & Average & Signification & Conclusion \\
\hline Experiment & 28 & 272.25 & 90.75 & & $\begin{array}{l}\text { Significance } 0.000<0.05 \\
\text { (H o rejected, } H_{1} \text { accepted) }\end{array}$ \\
\hline Control & 27 & 256.96 & 85.65 & 0.000 & \\
\hline
\end{tabular}

The results of the T-test showed a significance value of $0.000<0.05$ so that $\mathrm{HO}$ was rejected. It can be concluded that it is concluded that the use of the CTL-based Plant Physiology E-Module has an effect on student skill competency learning outcomes.

\section{B. Discussion}

The pandemic condition that requires learning to be carried out online (on the network) requires teaching staff to provide teaching materials that are suitable and effectively used to support the independent learning process carried out by students. Encouraging researchers to develop a product in the form of an e-module that can be used by students, with the aim of improving student learning outcomes, especially in the Plant Physiology course. Supported by the opinion of Rahmi, et al (2018) which states that teaching staff (lecturers) should be able to prepare everything needed in the learning process, one of which is teaching materials that are designed systematically, effectively and attract reading interest for students.

Based on the results obtained from the validation process, an average value of $92.21 \%$ was obtained with a very valid category. This is supported by the opinion of Arikunto (2013) which states that if a data obtained from the average assessment of a product is valid, it can be said that the product developed has been able to provide an impact in the form of an overview of the objectives of the development that is appropriate and correct with reality and reality. As for the validation aspects that have been reviewed from three aspects, namely: didactic aspects, construct aspects and technical aspects.

Based on the practical results that have been carried out on several respondents, including: small groups obtained an average of 87.98 in the very practical category, large groups obtained an average of 82.17 in the very practical category and lecturers in the course obtained an average of 95 in the very practical category. Paracticality refers to several aspects, namely: ease of use, efficiency in use, attractiveness, easy to interpret and has equivalence.

Another aspect is the efficiency of teaching materials when examined from the time that can be used in student learning, it can save learning time of course. Because this E-Module can be used anytime and anywhere, this is in line with Cahyadi's opinion (2019) which states that with the development of technology that can produce teaching materials according to the characteristics and needs of students, it makes it easier for them to transfer information and knowledge. easier and without the constraints of space and time.

Based on the attractiveness aspect, the developed E-Module has a very practical category. The CTL-based Plant Physiology EModule which was developed has an attractive appearance so as to increase student interest in learning and presenting material 


\section{Development of Plant Physiology E-Modules Based on Contextual Teaching and Learning (CTL) on Photosynthesis and Metabolism Materials Nitrogen Using Software Appypie of Results Student Learning Biology}

using a contextual approach, where the examples and videos used in the material are phenomena that occur in everyday life. this is one of the driving factors in improving student understanding and learning outcomes in learning. In line with research conducted by Apriyanti, et al. (2015) showed that the use of e-modules with a Contextual Teaching and Learning (CTL) approach can improve learning outcomes and make it easier for students to understand the subject matter because it is equipped with learning videos that are in accordance with their daily life experiences.

The aspect of ease in interpreting the CTL-based Plant Physiology E-Module has very practical criteria. This is because the use of the CTL-based Plant Physiology E-Module uses Appypie Software so that it is easy for lecturers to understand and easy for students to interpret. Setiani (2011) states that Appypie Software has the advantage that in designing an application it does not use coding or programming languages so that it is more effective and easy to use. This is in line with the opinion of Nugraha (2013) which states that the convenience obtained by users is one of the language standards or readability of teaching materials seen from the use of good and correct language in accordance with the KBBI, the use of simple and uncomplicated language will facilitate understanding. students about the material presented.

In terms of equivalence, the CTL-based Plant Physiology E-Module has very practical criteria. This shows that the E-Module has the equivalent of material with teaching materials that are commonly used, so that it can be an alternative teaching material in the learning process. The E-Modul has a presentation of material that is relevant to the syllabus, so it can be used as one of the variations of teaching materials used in Plant Physiology lectures. Sukardi (2012) states that E-Module is said to be equivalent if it can be used as a substitute or variation in learning according to student learning needs.

Based on the results of the effectiveness test that has been carried out, it includes knowledge competence, attitude competence and skill competence. In the knowledge competence, the researcher uses 25 objective questions which have been measured for validity, difficulty index and differentiating power. The results showed that the average of the experimental class was higher than the control class. Based on this, it was obtained that the data were normally distributed, homogeneous and the hypothesis $\mathrm{H} 1$ was accepted. Therefore, it can be concluded that CTL-based e-modules can affect student learning outcomes. In accordance with Nur (2017)'s opinion, which states that electronic modules can help students improve competence and cognitive understanding, and make it easier for students to learn the content of the material in e-modules because they are easy to carry anywhere and anytime.

Based on the research that has been carried out on the attitude competency assessment, the results show that the experimental class that uses the CTL-based plant physiology e-module is better than the control class that does not use the CTLbased plant physiology e-module. The assessment indicators in attitude competence observed by observers were cooperation, responsibility and student discipline in the learning process. conventional. There are differences in the character of students in the aspects of honesty, discipline, and responsibility. A contextual approach can improve the character of honesty, discipline and responsibility towards students.

The learning outcomes of student competency skills that have been obtained reveal that the experimental class using the emodule has a higher average score than the control class using the commonly used teaching materials (module). The criteria assessed in the PPT are appearance, conformity with the material and supporting media in the PPT. Student creativity will affect the making and appearance of the presented PPT. The better the student's creativity, the better the PPT presented will be in its presentation technique. This is because the PPT presentation can describe the level of understanding of students' concepts (Stein. 2006). This is in accordance with the opinion of Szaba (2000) which states that the better PPT is used in the learning process, the greater the opportunity for an increase in student learning outcomes.

\section{CONCLUSION}

Based on the results of the development of the Plant Physiology E-Module based on Contextual Teaching and Learning (CTL) on photosynthetic materials and nitrogen metabolism assisted by appypie software, it can be concluded several things, namely:

A. The E-Module that has been developed has validity with a very valid category;

B. E-Modules that have been developed have practicality in the very practical category;

C. E-Modules that have been developed have effectiveness in the very effective category.

\section{REFERENCES}

1) Aprianti. R, Desnita, dan Budi. E. 2015. Pengembangan Modul Berbasis Contextual Teaching And Learning (CTL) Dilengkapi Dengan Media Audiovisual Untuk Meningkatkan Hasil Belajar Fisika Peserta Didik SMA. Prosiding Seminar Nasional Fisika.

2) Arikunto, S. 2013. Dasar-Dasar Evaluasi Pendidikan. Jakarta: Bumi Aksara. 


\section{Development of Plant Physiology E-Modules Based on Contextual Teaching and Learning (CTL) on Photosynthesis and Metabolism Materials Nitrogen Using Software Appypie of Results Student Learning Biology}

3) Astuti. D. A. I., Dasmo., dan Sumarni. A. R. 2018. Pengembangan Media Pembelajaran Berbasis Android Dengan Menggunakan Aplikasi Appypie Di Smk Bina Mandiri Depok. Jurnal Pengabdian Kepada Masyarakat. 24 (2).

4) Astutia, A. D. 2017. Pengembangan Media Pembelajaran Fisika Mobile Learning Berbasis Android. JPPPF. 3(1).

5) Cahyadi, A. (2019). Pengembangan Media dan Sumber Belajar. Serang: Laksita Indonesia.

6) Nugraha, D. A., Binadja, A., dan Supartono. 2013. Pengembangan Bahan Ajar Reaksi Redoks Bervisi SETS Berorientasi Konstruktivistik. Journal ofInnovative Science Education. 2(1) : 27-34.

7) Nur, A. L., Nurul. A. R., dan Hayatun, N. A. 2017. Pengaruh Vidio Praktikum Dengan Modul Elektronik Terhadap Keterampilan Proses Pada Materi Stoikiometri Siswa Kelas X SMAN 2 Tidore Islands, Jurnal Pendidikan Kimia (JPKim). EISSN : 2549-3116, P-ISSN : 2085-3653, 9 (1) : 226.

8) Rahmi, L., Razak, A., Violita, Sumarmin, R. 2018. Development of Student's Worksheet with Inquiry Learning Model on Ecological and Environmental Changes for Class X Senior High School. International Journal of Science and High Technology, 6(2), 448-453.

9) Rahmawati, L. Supardi, K. I. Triastuti S. 2019. Contextual Teaching and Learning Integrated with Character Education to Improve Student's Motivation and Character in Concentration of Solutions Topic at Pharmacy Vocational School. Journal of Innovative Science Education. JISE 8 (3) : 239 - 247.

10) Setiani, Putria. 2011. Penggunaan Appypie Untuk Mengembangkan media Aplikasi Android Pada Pembelajaran Tumbuhan Hijau Di Kelas V Sekolah Dasar. Jambi: UNJA Press.

11) Stein, K. 2006. The dos and don'ts of PowerPoint presentations. Journal of the American Dietetic Association, 106(11), $1745-1748$.

12) Sukardi. 2012. Evaluasi Pendidikan Prinsip dan Operasionalnya. Jakarta: PT Bumi Aksara.

13) Szaba, A. dan Hastings, N. 2000. Using IT In The Undergraduate Classroom: Should We Replace The Blackboard With Powerpoint?. Computers \& Education, 35: 175-187. 